Research Paper

\title{
The Relationships between Emotions of Students, Teachers and Parents and Academic Performance in Science Course
}

\author{
Nahid Solaimani Shebailo ${ }^{* 1}$, Shahram Vahedi ${ }^{2}$, Shahrooz Nemati ${ }^{3}$ \\ 1. M.A. in Educational Psychology, Faculty of Education and Psychology, University of Tabriz, Tabriz, Iran \\ 2. Professor, Department of Psychology, Faculty of Education and Psychology, University of Tabriz, Tabriz, Iran \\ 3. Associate Professor, Department of Psychology, Faculty of Education and Psychology, University of Tabriz, Tabriz, Iran
}

Received: April 9, 2018

Accepted: December 13, 2018

\begin{abstract}
Background and Purpose: The quality of academic performance of students is influenced by various factors. Students in school not only acquire knowledge and cognitive skills, but also experience the pleasant and unpleasant excitements associated with learning and progress. The purpose of the present study was to investigate the relationships between emotions of students, teachers and parents with academic performance in science course.

Method: The present study was descriptive and correlational. The statistical papulation included all the $8^{\text {th }}$ grade female students studying in the schools of the Miandoab city during the academic year of 2017-2018, 330 of them were selected using cluster sampling method and completed the questionnaires of academic emotions of students (Pekrun et al., 2002) and academic emotions for the parents and teachers (Frenzel et al., 2009). Also, the first semester's score on science course was used to determine the academic performance. Data analysis was performed using correlation and regression method.

Results: The results of correlation test showed that there is a significant relationship between students' enjoyment and anxiety, and parents' and teachers' enjoyment and academic performance $(\mathrm{p}<0.05)$. Also with the exception of teachers'anxiety, there was a significant relationship between the emotions of parents and teachers and the students' emotions $(\mathrm{p}<0.05)$. Regression results showed that the students's enjoyment and anxiety and the enjoyment of teachers and parents were more contributing to the prediction of the students' academic performance.

Conclusion: Emotional responses of parents and teachers, especially enjoyment and anxiety, have educational implications for students. As a result, teachers and parents should be aware of their emotional experiences and pay attention to the importance and quality of their excitement.
\end{abstract}

Keywords: Academic emotion, parents, teacher, academic performance

Citation: Solaimani Shebailo N, Vahedi S, Nemati S. The relationships between emotions of students, teachers and parents with academic performance in science course. Quarterly Journal of Child Mental Health. 2019; 6(1): 188-199.

* Corresponding author: Nahid Solaimani Shebailo, M.A. in Educational Psychology, Faculty of Education and Psychology, University of Tabriz, Tabriz, Iran. 


\title{
رابطه هيجانهاى تحصيلى دانش آموزان، معلمان و والدين با عملكرد تحصيلى درس علوم
}

\author{
ناهيد سليمانى شبيلو"'، شهرام واحدى'، شهروز نعمتى" \\ 1. كار شناسى ارشد روانشناسى تربيتى، دانشكده روانشناسى و علوم تربيتى، دانشكاه تبر يز، ايران

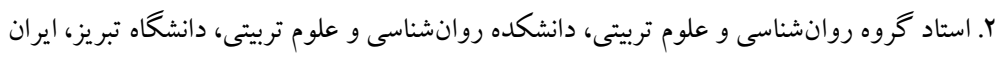

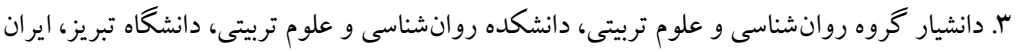

تاريخ بذيرش:

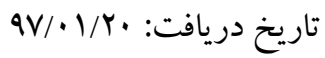

(1)

جكکب:

زمينه و هدف: كيفيت عملكرد تحصـيلى دانش آموزان تحت تأثير عوامل مختلفى اسـت. دانش آموزان در مدرســه نه تنها دانش و

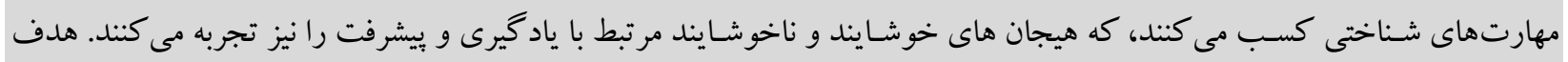

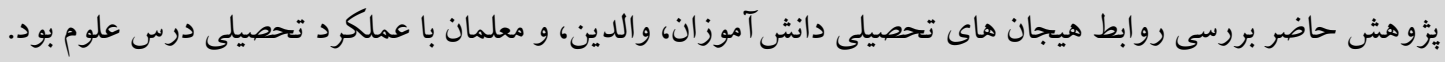

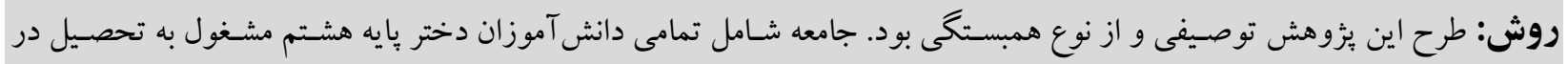

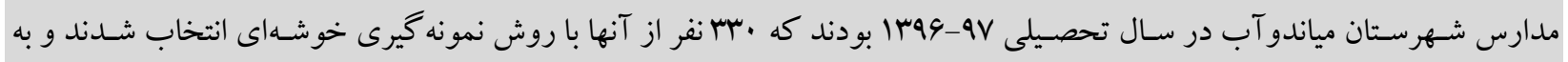

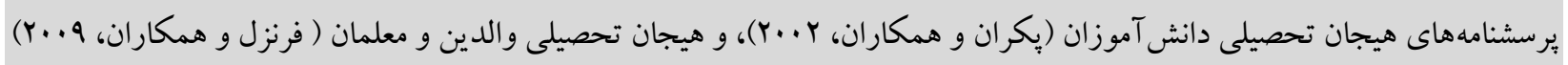

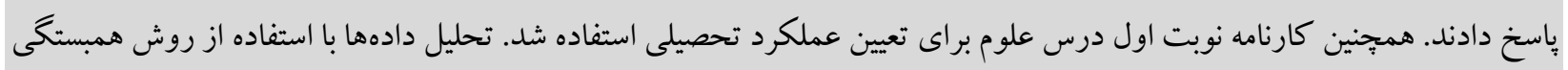
و ركرسيون همزمان انجام شد.

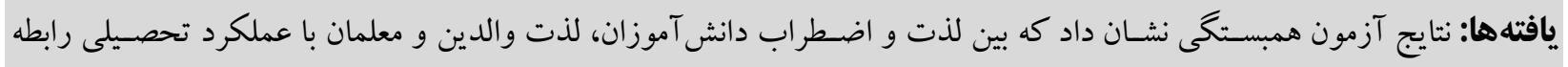

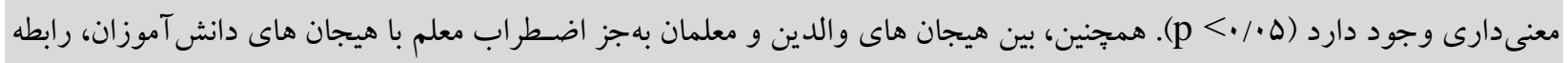

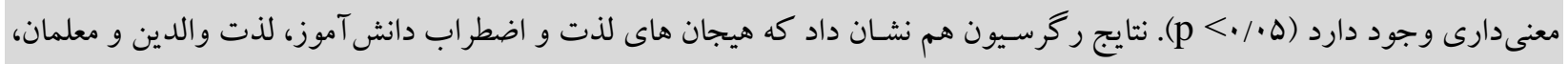
سهم بيشترى در ييشبينى عملكرد تحصيلى دانش آموزان دارند. نتيجه كيرى: واكنشهاى هيجانى والدين و معلمان بهويزه لذت و اضـطراب، بيامدهاى تحصـيلى براى دانش آموزان دارد در نتيجه

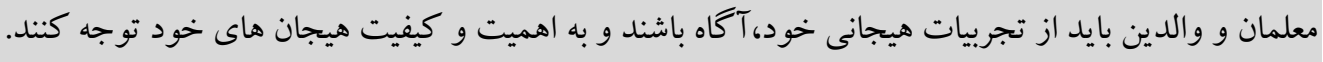
كليدوازهها: هيجان تحصيلى، والدين، معلم، عملكرد تحصيلى

*نويسنده مسئول: ناهيد سليمانى شبيلو، كار شناسى ارشد روانشناسى تربيتى، دانشكده روانشناسى و علوم تربيتى، دانشكاه تبريز، ايران.

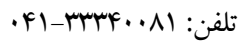
ايميل: Solimani96@ roshdmail.ir 
دربـاره نقش معلم در فراينـدهـاى يادگيرى دانش آموزان،

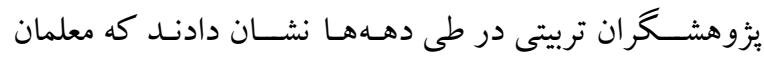

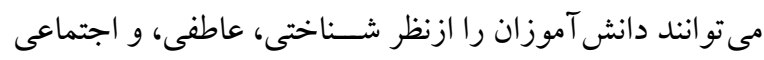

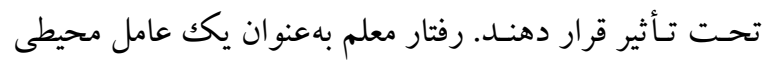

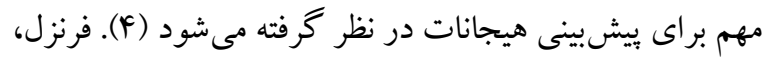

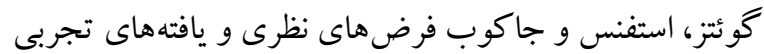

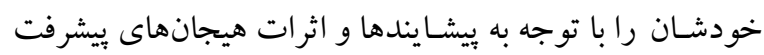

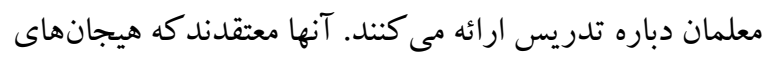

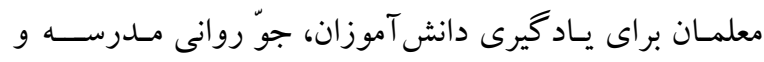

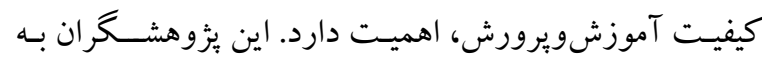

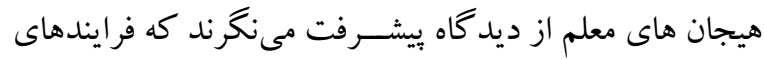
اصلى آن جستجوى موفقيت و اجتناب از شكست (هيجان هاى هـى مهري

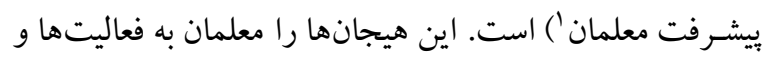
نتايج ييشـرفت تحصسيلى دانش آموز ان نشـان مىدهند و نتيجه

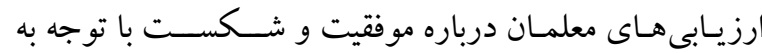

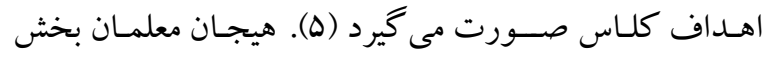
مهمى در بافت آموزشـى اسـت و با يبامدهاى مهم و مختلفى

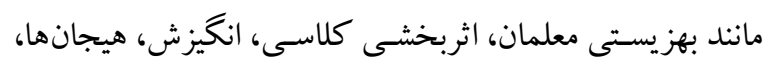
عملكرد و ياد گيرى دانش آموزان، ارتباط دارد (9).

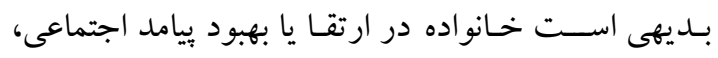
عـاطفى، و رفتـارى دانش آموزان نقش بســيـار مهمى را ايفـا

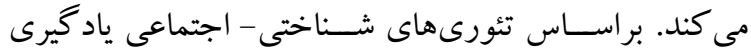
واكنشهاى هيجانى در تعاملات والد-كود كك، سرمشقدهى و

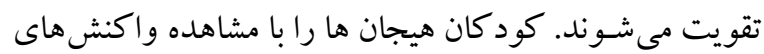

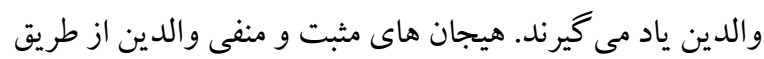
تعاملات والد-كودك،، هيجانهاى كودكان را تحت تأثير قرار

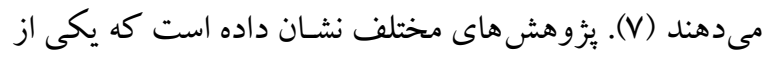
منـابع مهم شــكل گيرى هيجـانهـاى مثبت و منفى كود كان، واكنش هاى هيجانى والدين اسـت (V). هيجان هاى تحصـيلى

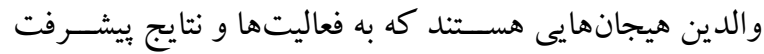
تحصيلى فرزندان خود نشان مىدهند (^).

\section{مقدمه}

يكى از شاخصهـهـى كيفيـت نظسام آموزشـى و اثربخشـى

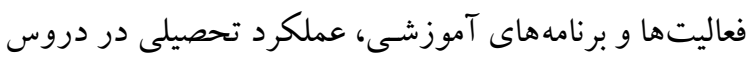

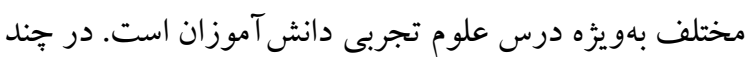

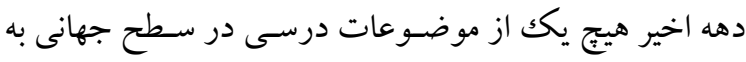

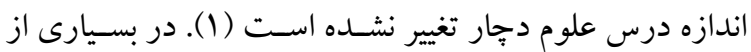

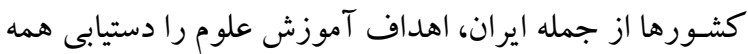

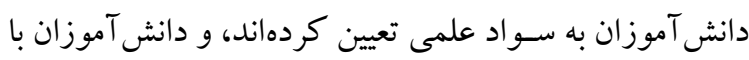

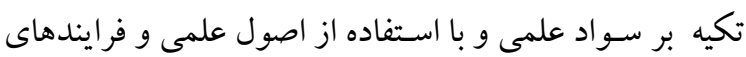

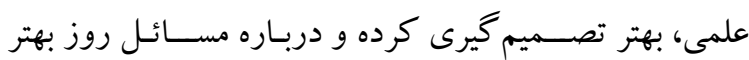

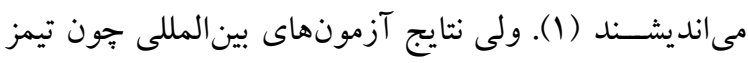
نشان مىدهد كه ايران از آن دسته كشورهايى است كه جايگاه

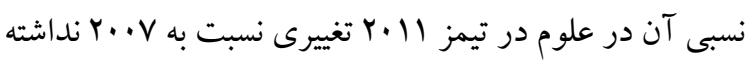
است و حتى در تيمز ها ب ب بهطور معنادارى بايين تر از ميانخين

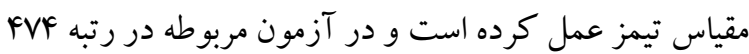
و بِايين تر از متوسط جهانى است (Y). عملكرد تحصيلى دانش آموزان تحت تأثير عوامل مختلفى

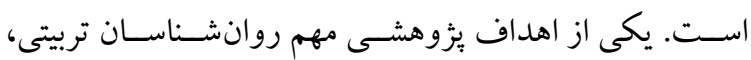
بررسى اين عوامل اسـت. روانشــاسان معتقدند دانش آموزان در طى آموزش نه تنها به كسب دانش و مهارت هاى شناختى نائل مىشوند، كه هيجان هاى خوشايند و ناخوشايند مرتبط يا لهوري

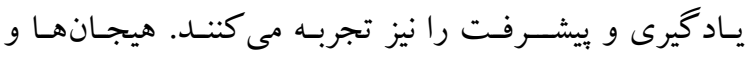

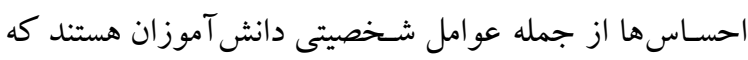

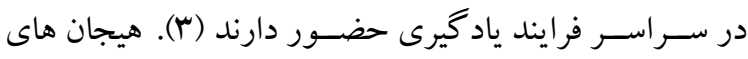

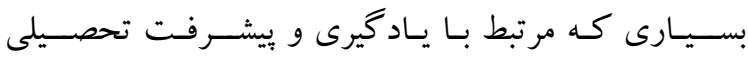
دانش آموزان است بهعنوان هيجانهاى محيطهاى تحصيلى در

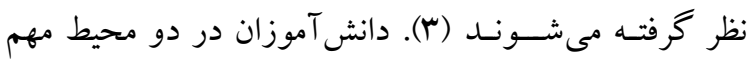

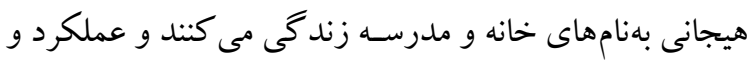

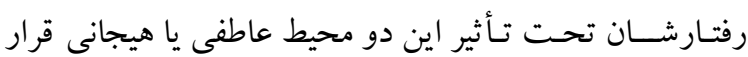

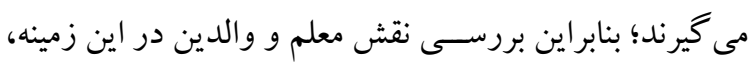

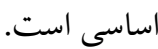

1. Teachers' achievement emotions 
نظريسه ارزش- مهـارگرى' در حسال حساضـر يكى از

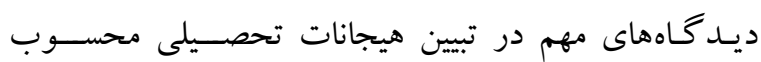

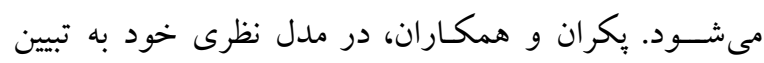
ييشـايندها و بيامدهاى هيجانات تحصسيلى مى يردازند. از نظر

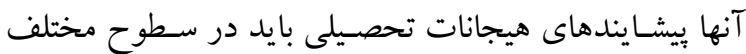

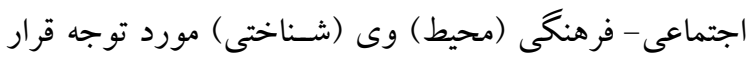

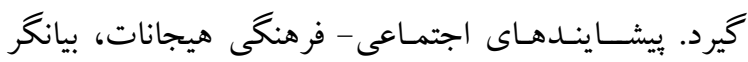

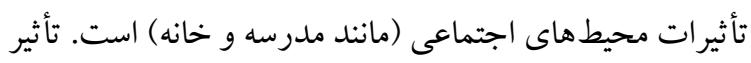

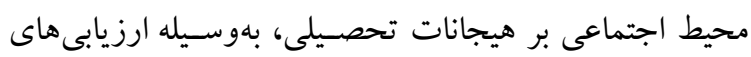

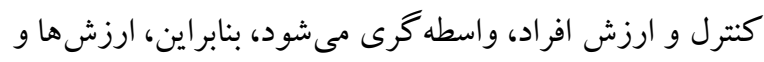
انتظارات والـدين و بهويزه هيجان هاى والدين (و هيجان هاى

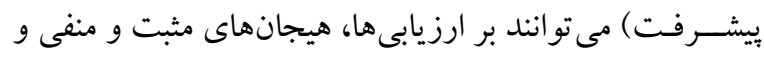
منابع عملكرد تحصسيلى دانش آموزان، تأثير داشـته باشـند (r).

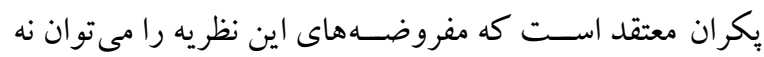
فقط براى تبيين هيجانهاى دانش آموزان، كه براى هيجانهاى

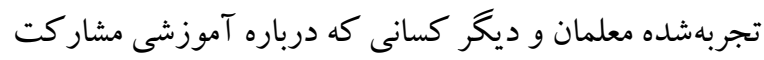

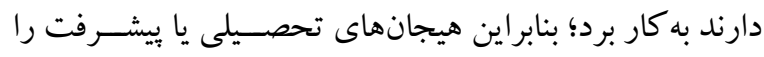

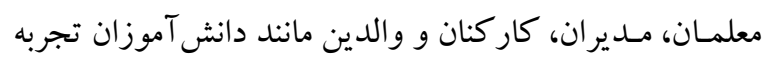

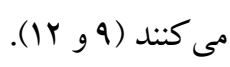

با توجه به مباحث فوق هيجانهاى دانش آموزان، والدين و معلمان با عملكرد تحصيلى رابطه دارند (YF-IV) ولى بررسى

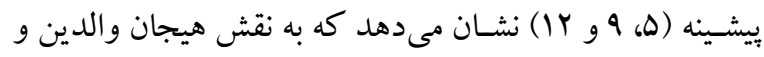

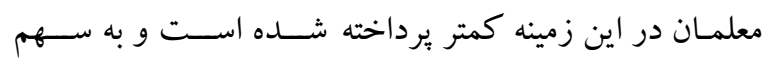
تفكيكى هيجانها در بيش بينى عملكرد تحصـيلى درس علوم

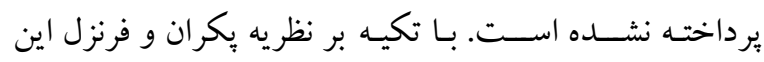

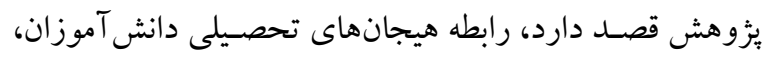

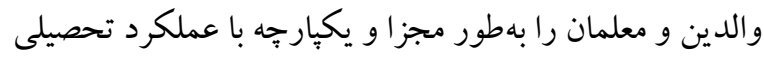

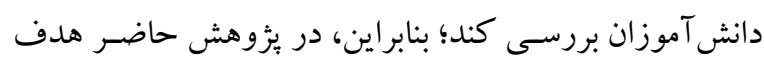
كلى اين است كه است كه هيجانهاى سه گروه دانش آموزان،
بِدر و مادر عامل اصلى تحول هيجانها در طول سـالهاى قبل از مدرسـه هسـتند. افتخار موفقيت و شـرم از شـكست، در

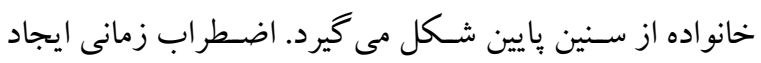

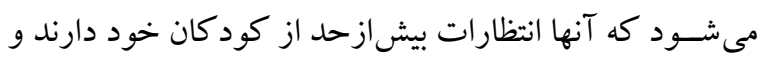
كو د كانشـان را به خاطر شـكسـت، تنبيه مى كنند. دانش آموزان زمانى بهطور مثبت رشــــ مى كنند و خيلى موفق مى شــوند كه

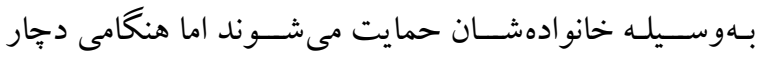
شـكست مىشـوند كه آنها با مخالفت خانواده، مو اجه شـوند؛

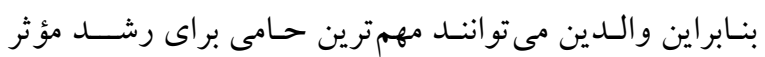
دانش آموزان باشند (9).

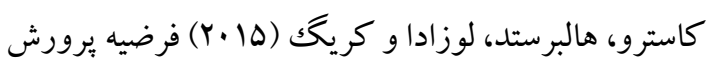
مهارت هـاى بـازشــناسـى هيجانى كود كان بهعنوان كار كرد

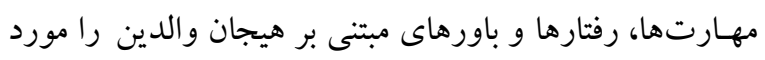

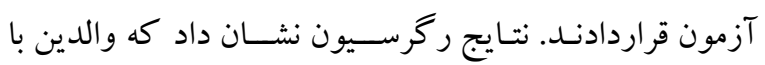

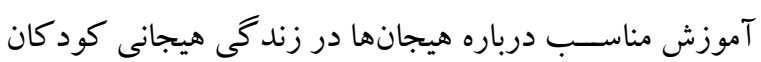

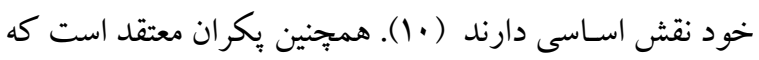
دانش آموزان بـايه هشــتم اغلب هيجانهايى مانند لذت، اميد، غرور، خشـم، و اضسطراب را در مدرسـه تجربه مى كنند. (11).

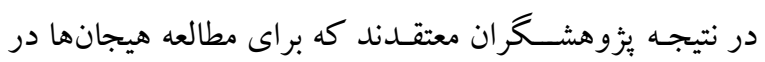
محيطهاى تحصيلى، نياز بيشترى وجود دارد.

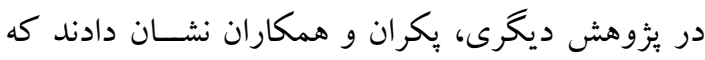
هيجانهاى مثبت (لذت، غرور)، يبشــــت هاى بعدى (نمرات

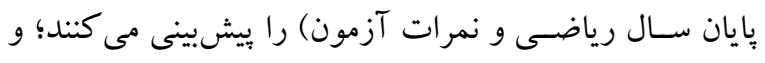

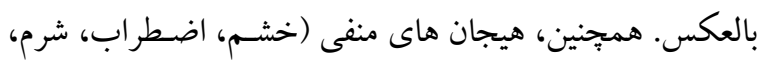

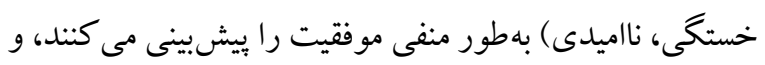
موفقيت نيز اين هيجانها را بهصسورت منفى بيشبينى مي كند.

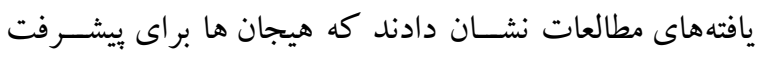

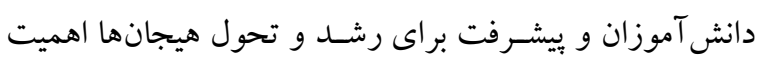

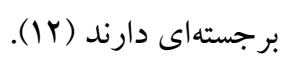


194•، غرور هD/ • و كل سـؤالها سN/ • به دسـت آمد. نتايج همجينين نشـان داد كه يرسشــنامه از همسـانى درونى و روايى مطلوبى نيز برخوردار است.

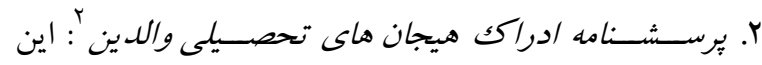

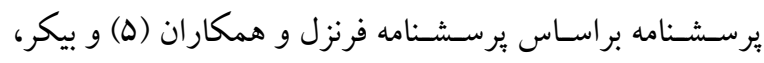

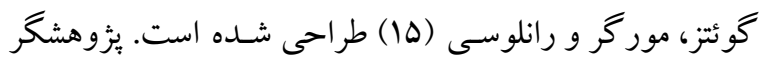

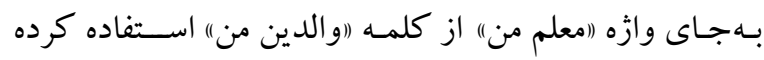

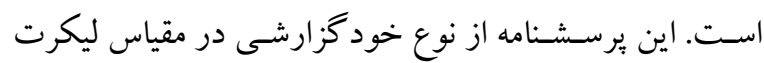

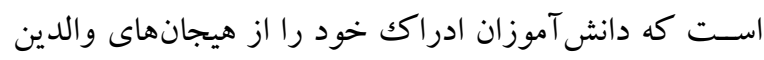

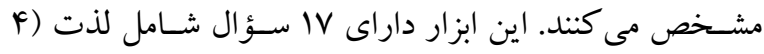

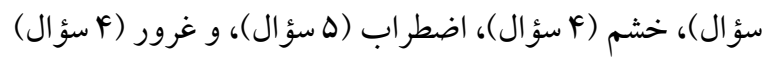
اســت. در اين ئزوهش بـايايى برسـشــــامه با آلفاى كرانباخ

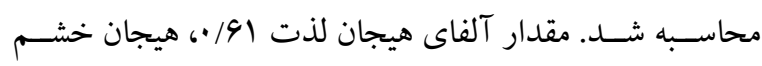

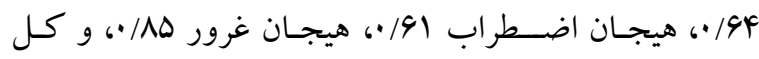

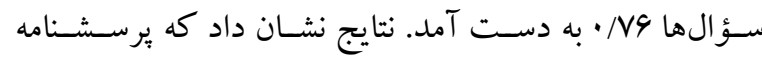
همسانى درونى مناسبى دارد (ه و ها ).

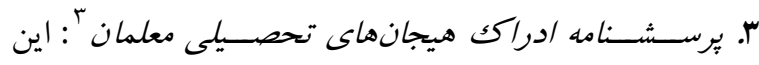

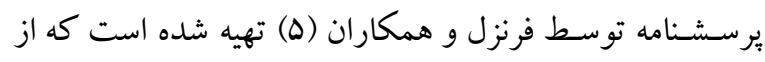
نوع خود زارشسى در مقياس ليكرت اسـت كه دانش آموزان

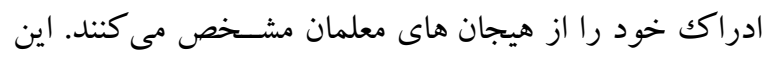
ابزار داراى IV سؤال و جهار مقياس شـامل لذت (F سؤال)،

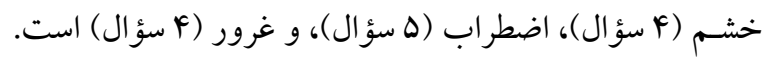
مؤلف اين تسـت، شـاخص هاى روانسـنجى آن را مطلوب و و

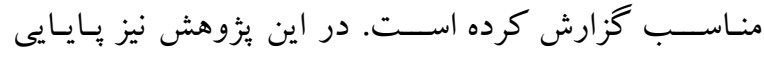

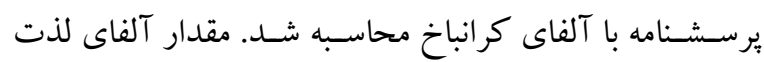

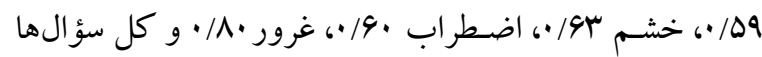
Pr/ • بـه دسـت آمد كه حاكى از همسـانى درونى مطلوب يرسـشـنامه است. همجِنين روايى اين ابزار توسط متخصصان و سازنده تست، تأييد شده است.

3. The achievement emotions questionnaire of Teachers
والـدين، و معلم تـا جه حد در يِشبينى عملكرد تحصـيلى

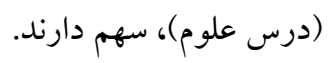

\section{روش}

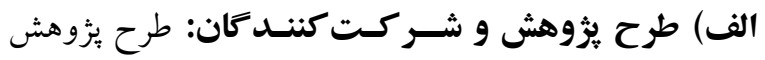

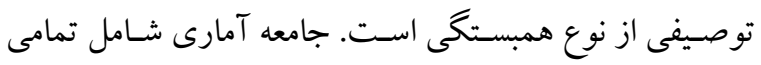

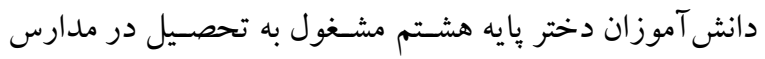

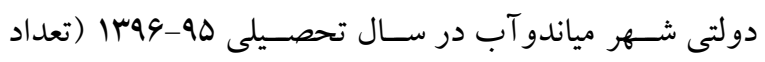

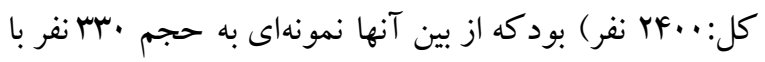

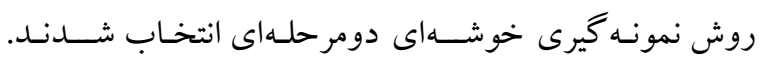

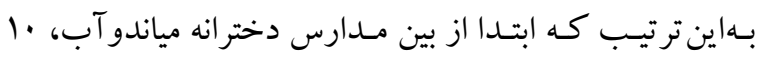
مدرسـه بهصورت تصادفى انتخاب شدند، سيس در هر مدرسه

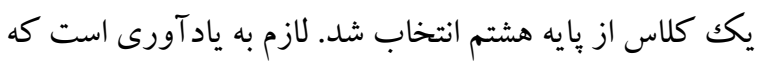

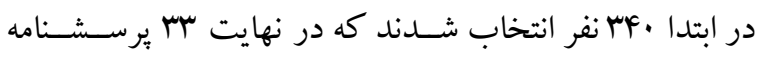
كامل شـده و وارد تحليل شـدند. شرط ورود به ئزوهش شامل

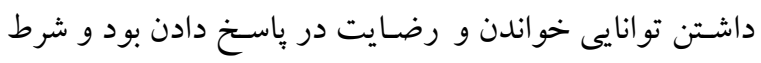

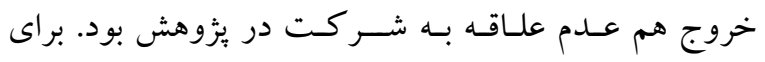
جمع آورى اطلاعات از ابزارهاى زير استفاده شد.

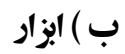
ا. برسـشــامه هيجانهاى تحصسيلى' دانش آموز بِكران: اين

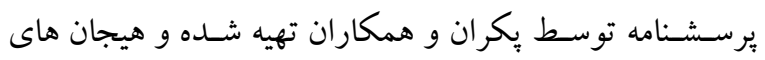
دانش آموزان را در موقعيتهاى ياد گيرى اندازه كيرى مى كند.

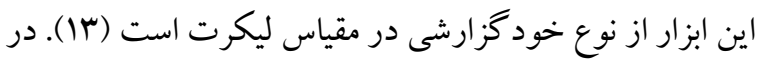

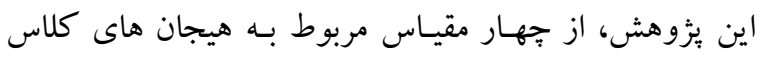

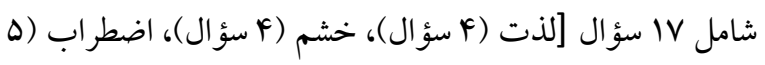
سؤال) و غرور (F سؤال)] استفاده شد.

در يُزوهش كديور، فرزاد، كاووسسى و نيكدل (IF) اعتبار

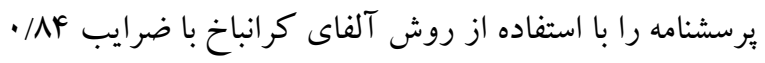

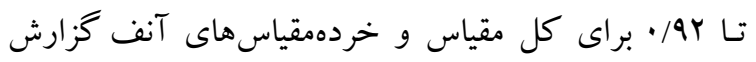
كردند. در هُزوهش حاضر نيز بايايى برسشنامه با بـ آلفاى كرانباخ

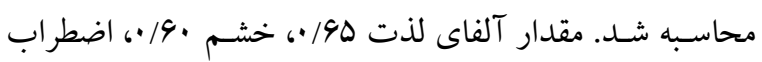

1. The achievement emotions questionnaire (AEQ) 2. The achievement emotions questionnaire of Parents 
اطلـاعات هر فرد كاملا محرمانه باقى مىماند. در بِيان دادههاى

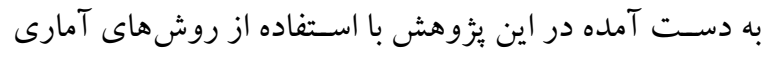

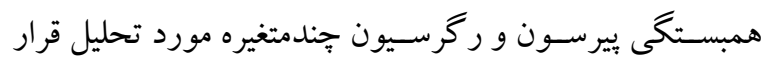

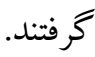

\section{يافتهها}

در جدول ا شـاخص هاى توصسيفى متغيرهاى يُوهش اعم از

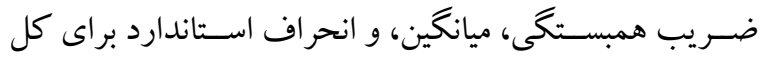
نمونه يُزوهش گزارش شده است. اشرفى و نجاتى بر اين باورند

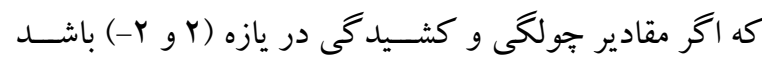

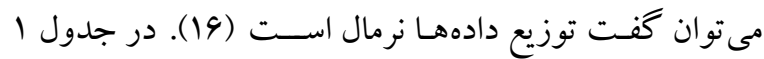

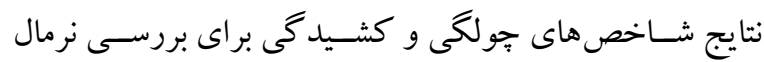

$$
\text { بودن توزيع متغيرها گزارش شده است. }
$$

Гا./رزيابى عملكرد تحصيلى: در اين مطالعه با استفاده از كارنامه

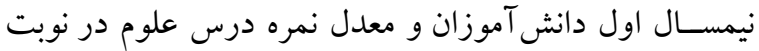
اول، براى ارزيابى عملكرد تحصيلى استفاده شد. ج) روش اجرا: جهت انتخاب افراد نمونه ابتدا مجوزهاى للازم

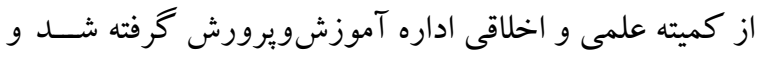

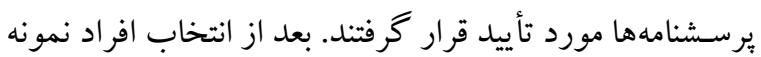
جهـت اجر اى يزوهش تمـامى ملـاحظـات اخلـاقى نيز بـه طور كامل رعايت شـده است. بدين منظور، آزمودنىها قبل از آغاز

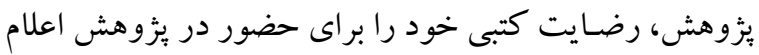

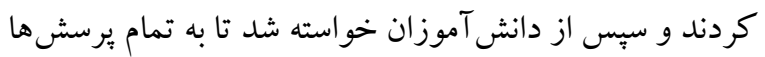
ياسخ دهند و درصورتى كه متوجه سؤ الى نشدند از معلم كمكك

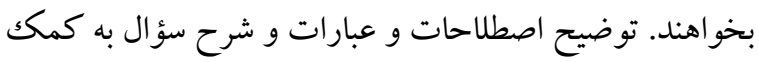

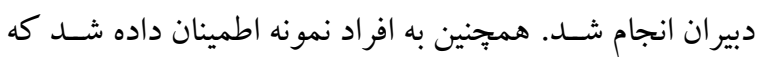

\begin{tabular}{|c|c|c|c|c|c|}
\hline كشيدكى & جولكى & انحراف استاندارد & ميانكين & ضريب همبستىى & متغير ها \\
\hline$-\cdot / 9 Y 1$ & $-/ M V q$ & $r / N$ & $1 \Delta / r \mu q$ & 1 & عملكرد تحصيلى \\
\hline /VII & $-1 / \cdot k r$ & $r / 99$ & $19 / 909$ & $\cdot / r V^{* * *}$ & هيجان لذت دانش آموز \\
\hline$-1 / 119$ & $-\cdot$ rar & $\Delta / Y q$ & $1 T / \Delta 9 Y$ & .1 .9 & هيجان غرور دانش آموز \\
\hline$-19 \mathrm{YV}$ & $-\cdot / r 19$ & $r / \Delta \Delta$ & IY/GYV & $\% \mu r$ & هيجان خشم دانش آموز \\
\hline $1 / 1 \Delta F$ & $-\cdot 1909$ & r/49 & $1 V / 91$. & $-\cdot / Y \Lambda^{* * *}$ & هيجان اضطراب دانش آموز \\
\hline I/VY. & $-1 / \Delta 49$ & $r / M r$ & IN/TrY & $\cdot / r Y^{* * *}$ & هيجان لذت والدين \\
\hline-194. & $-\cdot / 9 \Lambda Y$ & $F / W$ & $1 F / 0 \ldots$ & $-\cdot / \cdot r$ & هيجان غرور والدين \\
\hline$-\cdot / r \Delta \Lambda$ & $-\cdot / r Y \mid$ & $r / 94$ & $|r / \wedge \Delta|$ & $-\cdot / \cdot \Delta$ & هيجان خشم والدين \\
\hline.$/ r \Delta$ & $-\cdot / \Delta \cdot 1$ & $r / q$. & IN/Arq & $1 \cdot 4$ & هيجان اضطراب والدين \\
\hline .1909 & $-\cdot / 994$ & $r / 4$. & $19 / 1 \mathrm{VI}$ & $\cdot /\left.r\right|^{* * *}$ & هيجان لذت معلم \\
\hline$-\cdot / \cdot 19$ & $-\cdot 1919$ & $f / r$. & IF/TYG & $\cdot / \cdot v$ & هيجان غرور معلم \\
\hline$-\cdot / \Delta r q$ & $-\cdot / M M$ & (r/ & $\mid r / V M A$ & $-\cdot / \cdot r$ & هيجان خشم معلم \\
\hline.$/ F Y$ & $-\cdot / r \Delta \Lambda$ & $r / \Delta r$ & $19 / 199$ & $.1 \cdot 9$ & هيجان اضطراب معلم \\
\hline
\end{tabular}

تحصيلى r=- محاسبه شـده اسـت. اين مقادير در سطح كمتر از 1 ••• معنىدار اسـت، در نتيجه فرض صـفر رد شـده و فرض يثوهش تأييد مى شود. مقدار ضريب همبستخى بين لذت

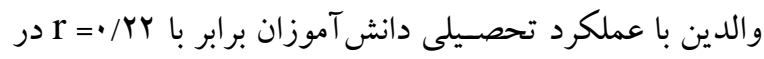
سـطح كمتر از 1 ×• معنىدار اسـت ولى هيجانهاى غرور،

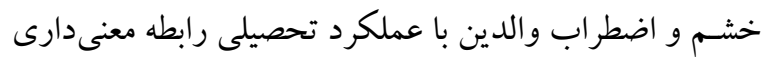

r) با تو جه به جدول ا مقادير جولكى و كشيدگى در بازه و Y-) اسـت بنابر اين مى توان نتيجه گرفت توزيع متغيرها نرمال

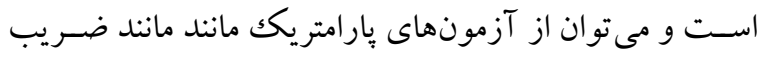

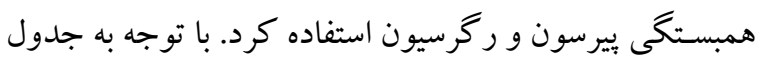

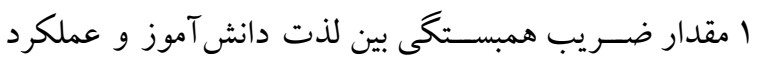

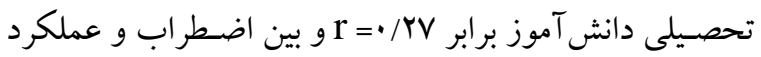


بـا عملكرد تحصـيلى رابطه معنىدارى ندارند. در جدول r

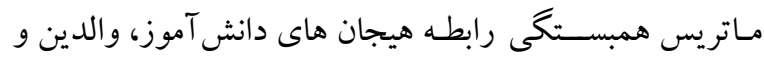
معلم با عملكرد تحصيلى گزارش هده راست هيجان هائ
ندارند. مقدار ضـريب همبسـتخى بين لذت معلمان با عملكرد

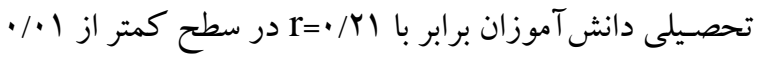
معنى دار است ولى هيجان هاى غرور، خشم و اضطر اب معلمان

\begin{tabular}{|c|c|c|c|c|}
\hline اضطراب دانش آموز & خشم دانش آموز & غرور دانش آموز & لذت دانش آموز & متغير هيجان ها \\
\hline$-\bullet / 1$ & $\cdot / \cdot r$ & $\cdot / \cdot 1$ & $\cdot / q^{* \text { *** }}$ & لذت و الدين \\
\hline$-.1 \cdot 9$ & $\cdot / \cdot \Delta$ & $\cdot / \Delta \Lambda^{* * *}$ & $\cdot / \cdot v$ & غرور والدين \\
\hline$\cdot / \cdot 9$ & $\cdot / Y^{* * * *}$ & $* / / r$ & $-\cdot / / \varphi^{*}$ & خشم والدين \\
\hline$-\cdot /\left.Y\right|^{* * *}$ & 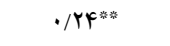 & $\cdot / 1$ ** & .1 .9 & اضطراب والدين \\
\hline$-1 \cdot .1$ & $-\cdot / \Lambda \Lambda^{* * *}$ &.$/ .9$ & $\cdot / 4 \Delta^{* * * *}$ & لذت معلم \\
\hline.$- / . r$ &.$/ .4$ & $\cdot / \mu \Delta^{* * *}$ & $\cdot / 11^{*}$ & غرور معلم \\
\hline.$/$ & $\cdot / 19^{\text {㫧絭 }}$ & $\cdot / \cdot V$ & $-\cdot / \cdot \Delta$ & خشم معلم \\
\hline .1 .09 &.$/ . r$ & $\cdot / 19^{* * *}$ & $\cdot / 1 Q^{* * *}$ & اضطراب معلم \\
\hline
\end{tabular}

غرور و خشــم معلمان به دانش آموزان رد مىشــود و فرضـيه يثزوهش در مورد سه هيجان لذت، غرور و خشم تأييد مى شود.

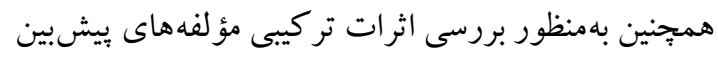

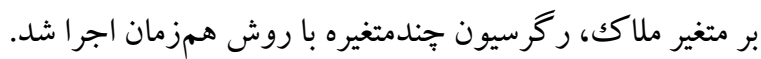

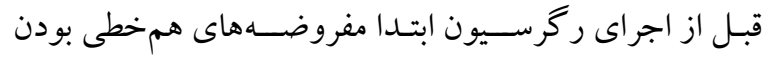

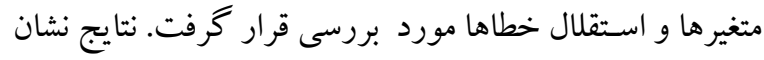
داد كه شاخص تحمل (تولر انس) براى تمام تغييرهاى بيشبين

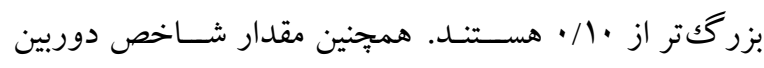

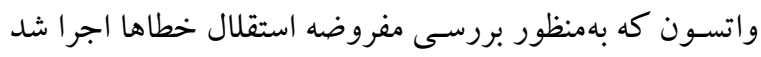

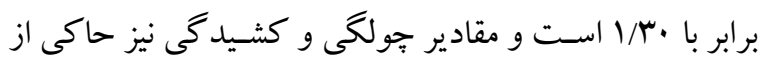

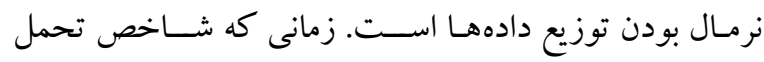

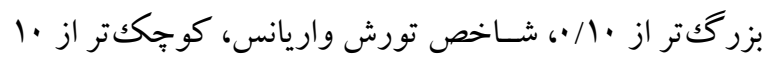

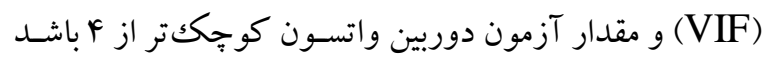

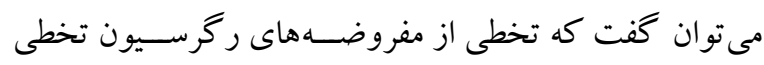

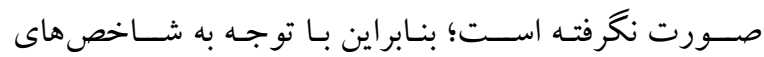

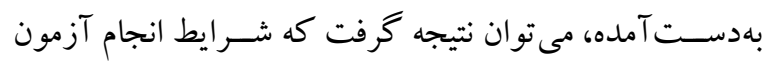
ركرسيون رعايت شده است.

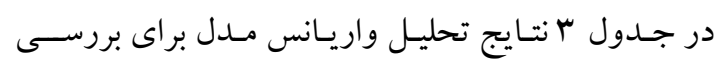
توانسيى بيشبينى تغيير عملكرد تحصــيلى از روى ســه متيير
براسـاس نتايج مندرج در جدول r كه از اجراى آزمون همبستخى بيرسون حاصلشده است، بين هيجان هاى والدين و

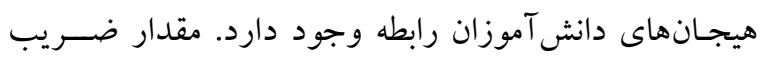
همبستكى بين لذت والدين و لذت دانش آموزان بr/

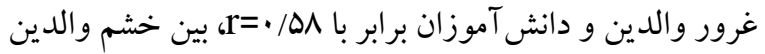

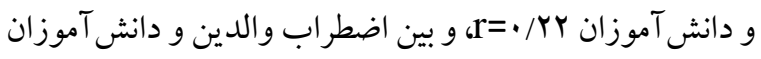

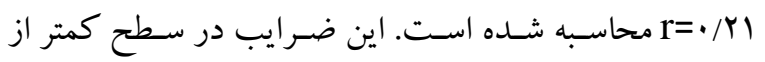
1 • • معنى دار هسـتند، در نتيجه فرض صـفر در مورد رابطه

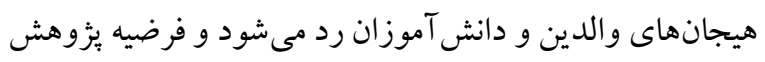

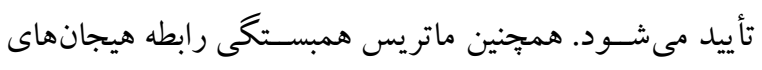

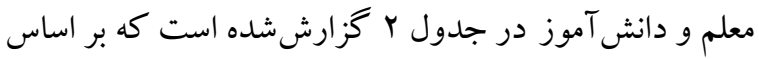
آن مقدار ضـريب همبستخى بين هيجان لذت معلمان و هيجان

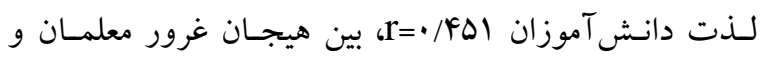

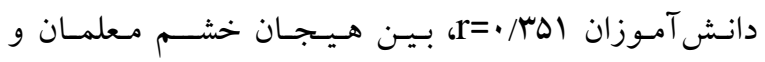
دانش آموزان برابر با r=/194، و بين هيجان اضطر اب والدين

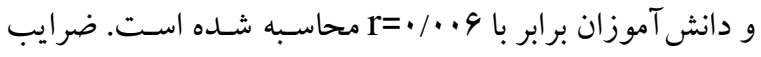
هيجـان هـاى لـذت، غرور و خشـــم در ســطح كمتر از 1 •/.

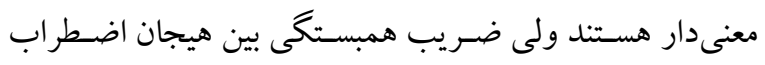

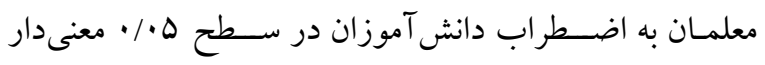
نيسـت. در نتيجه فرض صـفر در مورد رابطه هيجان هاى لذت، 
يبشبين دانش آموز، هيجان والدين و هيجان معلم گزارش شده

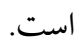

\begin{tabular}{|c|c|c|c|c|c|}
\hline سطح معنادارى & $\mathbf{F}$ & ميانكين مجذورات & درجه آزادى & مجموع مجذورات & منبع تغييرات \\
\hline \multirow[t]{3}{*}{.$/ .1$} & $9 / \pi k$ & $V Y / F \Lambda$ & ir & $199 / 11$ & ركرسيون \\
\hline & & $11 / 91$ & $r \cdot r$ & $r \Delta|V / 9|$ & باقيمانده \\
\hline & & & Mo & FrAV/VI & كل \\
\hline
\end{tabular}

كـه اين مقـدار بيـانگر آن اســت كـه هيجـانهـاى تحصـيلى

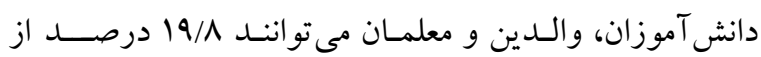

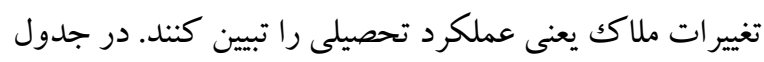

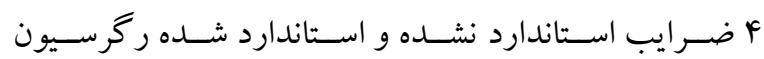
كزارش شده است.

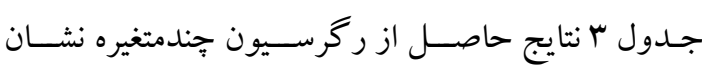

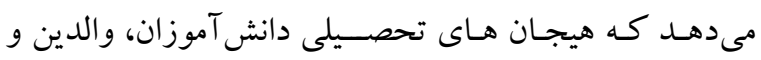

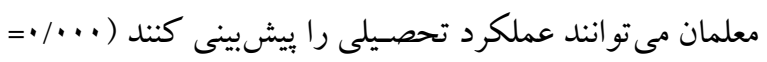
p و F/YF

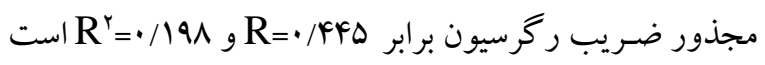

جدول ع: ضرايب ركرسيون استاندارد نشده و استانداردشده مدل ييشينى عملكرد تحصيلى

\begin{tabular}{|c|c|c|c|c|c|c|c|c|}
\hline واريانس & تحمل & سطح معنادارى & $\mathrm{T}$ & رخر ريون بتا & خطاى انحراف & B & متيشير هاى & \\
\hline- & - & $\cdot / \cdot 1$ & $F / \Delta 1$ & - & $r / \Delta r$ & $11 / \% 4$ & عدد ثابت & \multirow{6}{*}{ ديجانهاى } \\
\hline I/FF & $\cdot / \mathrm{V}$ & $.1 \cdot 19$ & T/Fr &.$/ 149$ & $\cdot / \cdot 19$ & $\cdot / r 1$ & لذت & \\
\hline $1 / 94$ & .194 & $\cdot / r \cdot \Lambda$ & $1 / 49$ & $\cdot / \cdot \wedge r$ & .1 .49 & .1 .9 & غرور & \\
\hline $1 / 1$ & $\cdot / A \Delta$ & $\cdot / \cdot \wedge \Delta$ & $1 / V^{r}$ & $1.9 \mathrm{~V}$ & $.1 . \Delta 9$ &.$/ 1$ & خشم & \\
\hline $1 / 10$ & $\cdot /$ AV & $\cdot / \cdot 1$ & $-\Delta / \& q$ & $-\cdot / r \cdot r$ & $.1 . \Delta 9$ & L & اضطراب & \\
\hline $1 / 19$ & . $/ \Delta r$ & $\| \cdot r \mid$ & $r / r$ &.$/ 194$ & .1 .91 & $\cdot / I F$ & لذت & \\
\hline $1 / \mu F$ & $\cdot / V^{F}$ & . & $1 / r$. &.$/ \cdot V r$ & $\cdot / 1 \cdot \Delta$ & - & غرور & \multirow[t]{2}{*}{ هيجان هاى والدين } \\
\hline $1 / \Delta r$ & .199 & . A & $-\cdot / \wedge$ & -1.01 & .1 .90 &.$- / \cdot \Delta$ & خشم & \\
\hline $1 / \Delta F$ & .190 & . ו ו & $1 / \cdot 1$ & .1 .90 & .1 .91 & .1 .9 & اضطراب & \multirow{5}{*}{ هيجانهاى معلم } \\
\hline $1 / V V$ & $\cdot / \Delta \mathrm{V}$ &.$/ \cdots q$ & $r / 9 r$ & $\cdot / \Lambda$. & $\cdot / \cdot \wedge$ & $\cdot / r 1$ & لذت & \\
\hline $1 / 91$ & .194 & $\cdot / \mu r$ & $\cdot / \mathrm{Va}$ & $\cdot / \cdot \Delta r$ & $\cdot / \cdot \Delta \Lambda$ & $\cdot / \cdot \Delta$ & غرور & \\
\hline $1 / Y \Lambda$ & $\cdot / \mathrm{VA}$ & . /DGY & $\cdot / \Delta \Lambda$ &.$/ \cdot M F$ & .1 .99 &.$/ F$ & خشم & \\
\hline $1 / \mu \wedge$ & $\cdot / N r$ & $\cdot / Y M A$ & $-1 / r \mu$ & $-\cdot / \cdot V F$ & .1 .94 & $-\cdot / \cdot \wedge$ & اضطراب & \\
\hline
\end{tabular}

\section{بحث و نتيجه كيرى}

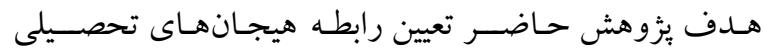

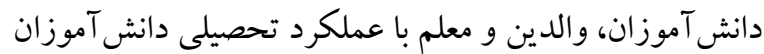

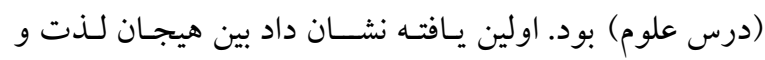

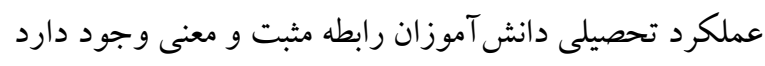

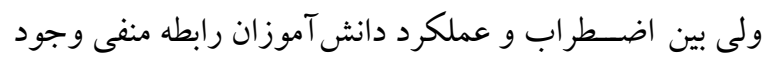

با توجه به جدول 9، ضر ايب رگرسيون استانداردشده نشان

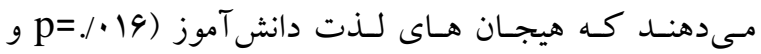

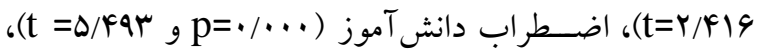

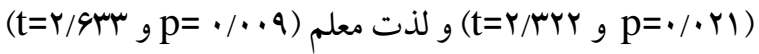

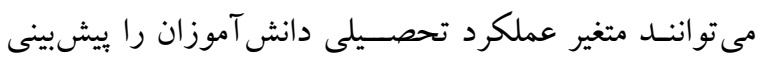
كنند. 
هيجانها (rr) اسـتناد كرد طبق اين نظريه احتمال دارد والدين

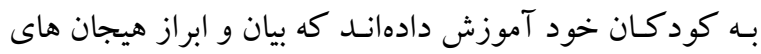

$$
\text { منفى را به حداقل بر سانند. }
$$

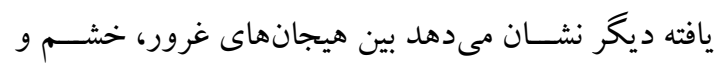

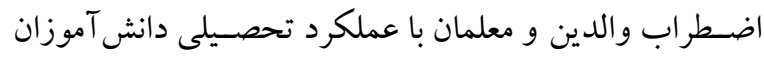
رابطه معنى دار وجود ندارد ولى بين هيجان لذت والدين و معلم با عملكرد تحصـيلى رابطه مثبت معنى وجود دارد. اين يافته با

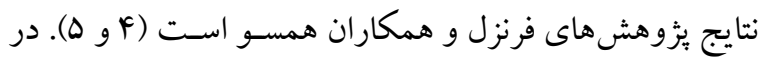

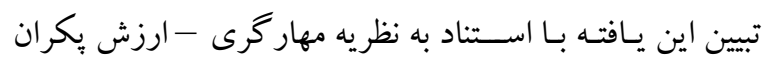

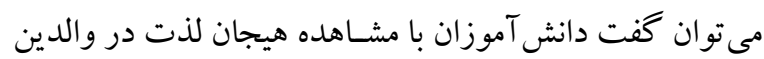
و معلمـان بهعنوان مؤلفه هاى محيطى، ارزيابى هاى مثبت مبتنى

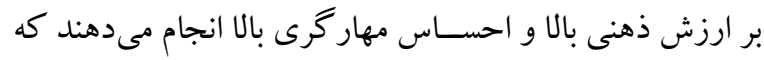

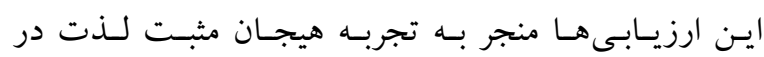

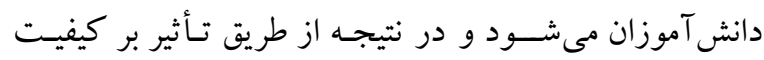

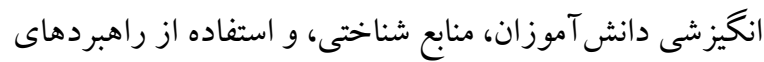

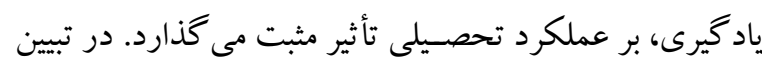

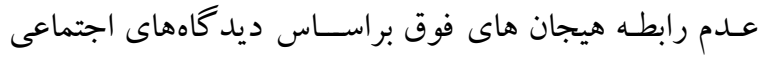
كردن مىتوان كفت كه دريافت واكنشهاى منفى والدين مثل هان خشــم و اضـطر اب توســـ كود كان موجب ياد گيرى هيجان اضــطراب در آنها مىشــود (Tr). هيجان غرور هم بهعنوان واكنش مثبـت، موجـب هيجان مثبت مانند لذت در فرزندان و

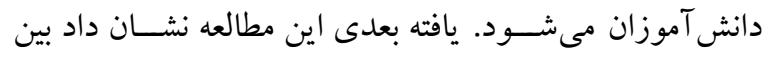

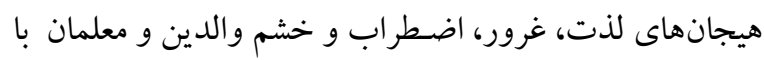

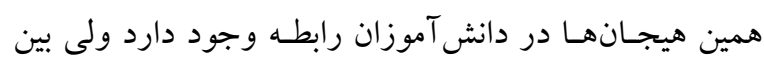
هيجـان اضـطر اب معلم با اضـطر اب دانش آموز رابطه وجود

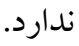

يافته فوق را مى توان با استناد به نظريه شناختى - اجتماعى كـ

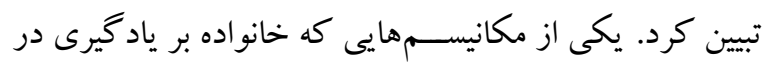

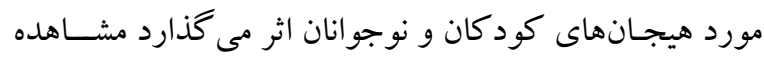

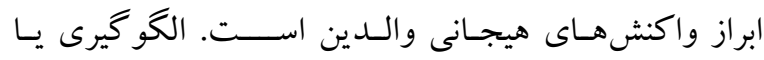

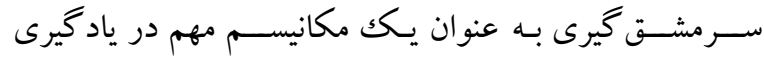
رفتارهاى معين به اثبات رسسيده اسـت. نظريه و بثرهش درباره
دارد و بين خشــم و غرور و عملكرد تحصسيلى رابطه معنىدار

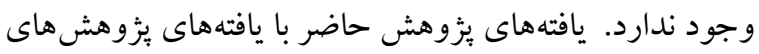

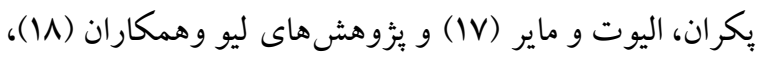
كارمونا-هالتى، سلانوا، لورنس و شاوفلى (19) و كاماكو -مارلز و همكاران (·r) همسو است.

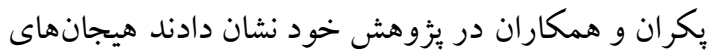
مثبت (از قبيل شـادى، نشـاط، لذت، خشــنودى، اميد و غرور )

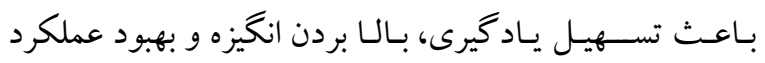

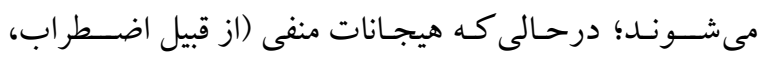

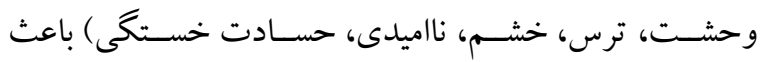

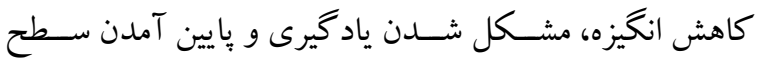

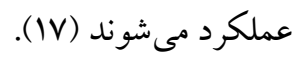

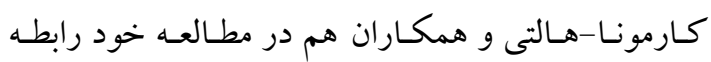
معنىدار هيجانهاى مثبت و عملكرد تحصسيلى را تأييد كردند

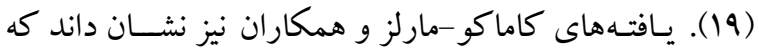
هيجانهاى مثبت و منفى تحصـيلى با عملكرد تحصـيلى رابطه معنى دارى دارد (·ץ). همجينين سينيو، اكلوند، آهونن و كيورو

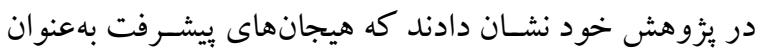
متغير واســــهاى بر عملكرد تحصــيلى اثر مى خـذارد (Y) (Y). مجموعه اين مطالعات به نوعى با نتايج مطالعه حاضـر همخو ان

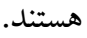
يافتهاى فوق را مىتوان با استناد به نظريه هيجان تحصيلى

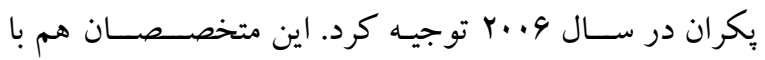
يُزوهش هاى خود درباره هيجانات مثبت به اين نتيجه رسيدهاند كه هيجانهاى فعال كننده مثبت، بيشـفت تحصيلى را از طريق افزايـش تـوجسه مبتنى بر تكليف، افزايش انخيزش، افزايش

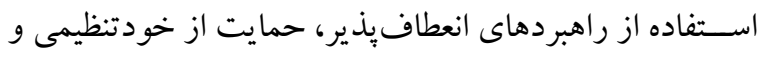

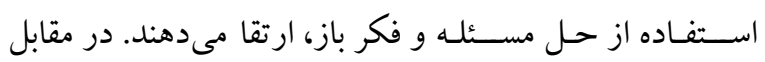
هيجانهاى فعال كننده منفى مانند اضطراب منجر به استفاده از بردازش سطحى اطلاعات و عملكرد بايين تحصيلى مى شود ( بـه نقل از r). در تبيين عدم وجود رابطه بين هيجان هاى غرور

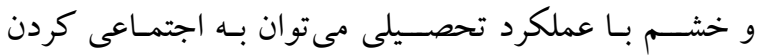


ممكن است مشار كت كنند كان را به استفاده از شيوههاى مبتنى

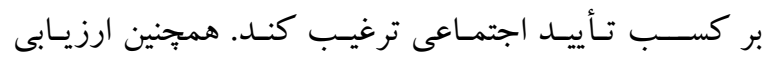

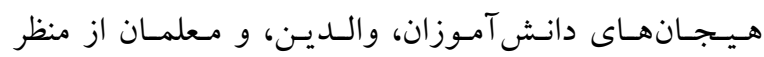

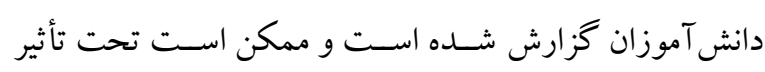

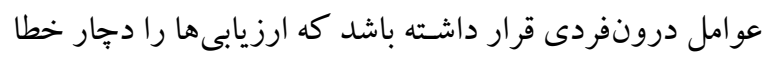
كند؛ بنابر اين توصيه مىشود مطالعات بعدى با رفع اين نو اقص بـ

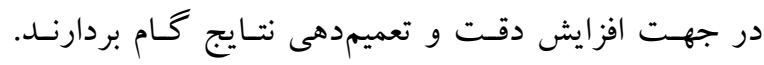
همجِين بايد توجه داشت كه اين يُوهش، تنها در درس علوم، و آن هم با متغيرهاى هيجان و ويشـرفت تحصسيلى انجام شـده ئه

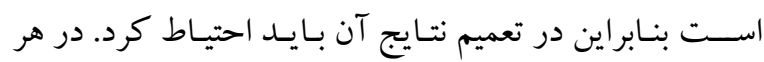

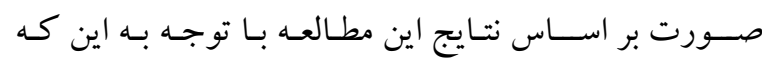

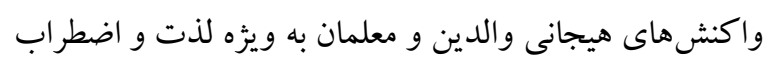

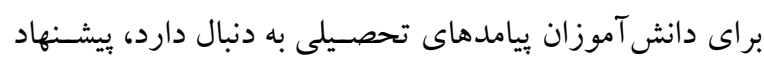

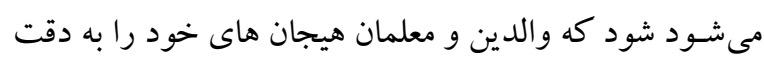
بشناسند و از ارزيابى هاى خود، آكاه باشند.

تشـكر و قدردانى: اين يزّوهش بر خرفته از بايانامه كارشـناسى

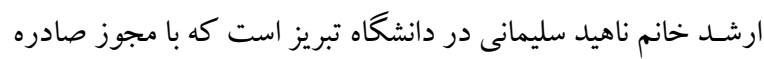

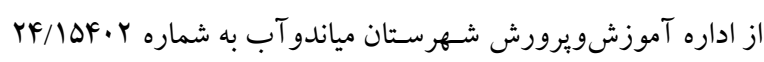
در سال تحصيلى وه-هوه ا اجر ا شد؛ بدينوسيله از استادهاى راهنما

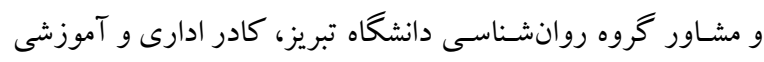

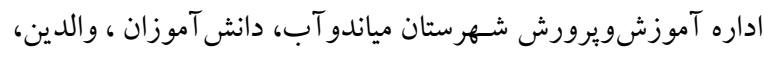

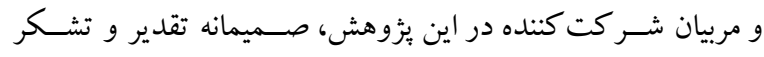

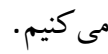
تضــاد منافع: بر اســاس گزارش نويســند كان، نتايج اين مطالعه

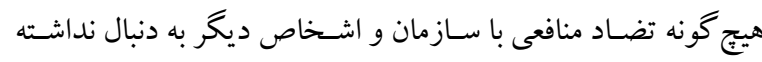
است.
الكو گيرى، ســرايت هيجانى و گرووهاى مرجع، شـــواهدى را

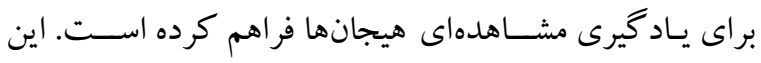

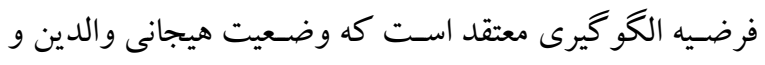

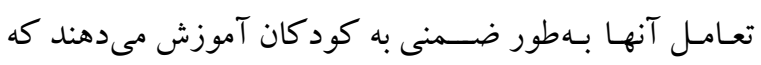

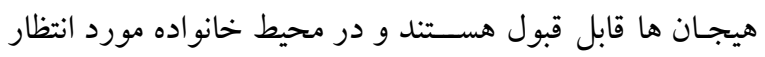
است (YY).

كودكان ياد مى گيرند كه در موقعيتهاى معين هيجان ها

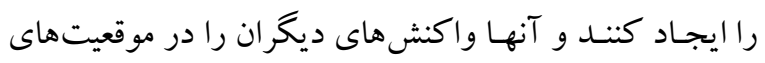

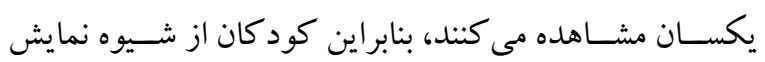

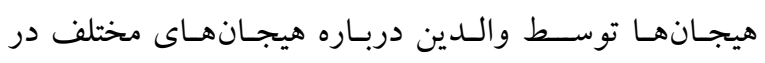
موقعيت هاى مختلف و انواع بِاســـخ هاى هيجانى، ياد مى گيرند

نتايج حاصل از ركرسيون همزمان نشان داد كه هيجانهاى

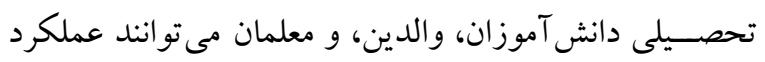

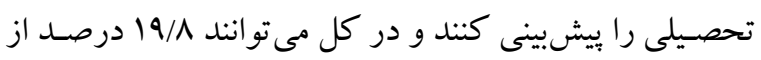

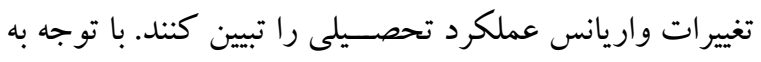
نتايج ركرسيون مشخص شد كه هيجانهاى لذت دانش آموز، اضطر اب دانش آموز، و لذت معلم سـهم بيشترى در ويشيشينى عملكرد تحصيلى دانش آموزان دارند. اين يافته با تكيه بر مدل

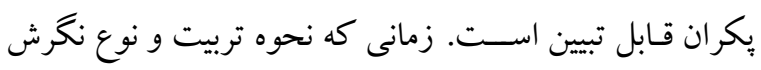

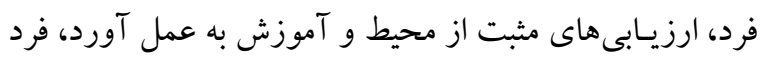
به احسـاس و هيجان مثبت دسـت مى يابد و تمام تلاش خود را

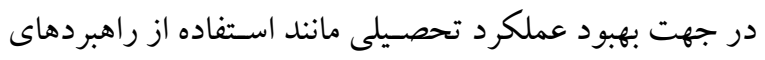

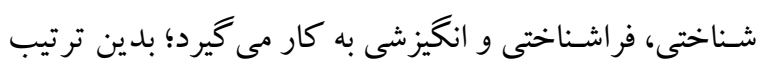

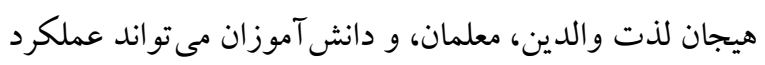

تحصيلى دانش آموزان را بهبود بخشد (11). نتايج مطالعه حاضـر هميجون بسيسارى از مطالعات ديخر به

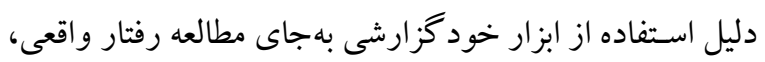




\section{Reference}

1. Taherizadeh S, Nateghi F, Faghihi A. The effects of teaching-learning patterns on students' educational improvement in empirical sciences: a meta-analysis. Journal of Curriculum Studies. 2018; 12(47): 95124. [Persian]. [Link]

2. Jafari M, Kiamanesh AR, Karimi A. A trend study and the role of attitude, interest in, and scientific selfconcept on scientific performance of eighth-grade students, based on international TIMSS studies. Quarterly Journal of Research in Educational Systems. 2017; 11(36): 89-120. [Persian]. [Link]

3. Lei H, Cui Y, Chiu MM. The relationship between teacher support and students' academic emotions: a meta-analysis. Front Psychol. 2018; 8: 2288. [Link]

4. Frenzel AC, Pekrun R, Goetz T. Girls and mathematics - A "hopeless" issue? A control-value approach to gender differences in emotions towards mathematics. European Journal of Psychology of Education. 2007; 22(4): 497-514. [Link]

5. Frenzel AC, Goetz T, Stephens EJ, Jacob B. Antecedents and effects of teachers' emotional experiences: an integrated perspective and empirical test. In: Schutz PA, Zembylas M, editors. Advances in teacher emotion research: the impact on teachers' lives. Boston, MA: Springer US; 2009, pp: 129-151. [Link]

6. Becker ES, Keller MM, Goetz T, Frenzel AC, Taxer JL. Antecedents of teachers' emotions in the classroom: an intraindividual approach. Front Psychol. 2015; 6: 635. [Link]

7. Morris AS, Silk JS, Steinberg L, Myers SS, Robinson LR. The role of the family context in the development of emotion regulation. Soc Dev. 2007; 16(2): 361-388. [Link]

8. Pekrun R. Academic emotions. In: Wentzel KR, Miele DB. Handbook of motivation at school. $2^{\text {nd }}$ ed. Routledge; 2016, pp: 120-144. [Link]

9. Pekrun R. Emotions and learning. The International Academy of Education. Belley: France; 2014, pp: 1-32. [Link]

10. Castro VL, Halberstadt AG, Lozada FT, Craig AB. Parents' emotion-related beliefs, behaviors, and skills predict children's recognition of emotion. Infant Child Dev. 2015; 24(1): 1-22. [Link]

11. Pekrun R. Emotion and achievement during adolescence. Child Dev Perspect. 2017; 11(3): 215-221. [Link]

12. Pekrun R, Lichtenfeld S, Marsh HW, Murayama K, Goetz T. Achievement emotions and academic performance: longitudinal models of reciprocal effects. Child Dev. 2017; 88(5): 1653-1670. [Link]

13. Pekrun R, Goetz T, Frenzel AC, Barchfeld P, Perry RP. Measuring emotions in students' learning and performance: the achievement emotions questionnaire (AEQ). Contemp Educ Psychol. 2011; 36(1): 3648. [Link]

14. Kadivar P, Farzad V, Kavousian J, Nikdel F. Validiting the Pekruns achievement emotion questionnaire. Educational Innovations. 2009; 8(4): 7-38. [Persian]. [Link]

15. Becker ES, Goetz T, Morger V, Ranellucci J. The importance of teachers' emotions and instructional behavior for their students' emotions - An experience sampling analysis. Teach Teach Educ. 2014; 43: 15-26. [Link]

16. Ashrafi HR, Nejati R. Applied statistics in plain language. Tehran: Tarbiat University of Rajai; 2010, pp: 53-56. [Persian]. [Link]

17. Pekrun R, Elliot AJ, Maier MA. Achievement goals and achievement emotions: testing a model of their joint relations with academic performance. J Educ Psychol. 2009; 101(1): 115-135. [Link]

18. Liu R-D, Zhen R, Ding Y, Liu Y, Wang J, Jiang R, et al. Teacher support and math engagement: roles of academic self-efficacy and positive emotions. Educ Psychol. 2018; 38(1): 3-16. [Link]

19. Carmona-Halty M, Salanova M, Llorens S, Schaufeli WB. How psychological capital mediates between study-related positive emotions and academic performance. J Happiness Stud. 2019; 20(2): 605-617. [Link]

20. Camacho-Morles J, Slemp GR, Oades LG, Morrish L, Scoular C. The role of achievement emotions in the collaborative problem-solving performance of adolescents. Learn Individ Differ. 2019; 70: 169-181. [Link] 
21. Sainio PJ, Eklund KM, Ahonen TPS, Kiuru NH. The role of learning difficulties in adolescents' academic emotions and academic achievement. J Learn Disabil. 2019; 22219419841567. [Link]

22. Nelson JA, O'Brien M, Blankson AN, Calkins SD, Keane SP. Family stress and parental responses to children's negative emotions: tests of the spillover, crossover, and compensatory hypotheses. J Fam Psychol. 2009; 23(5): 671-679. [Link]

23. Lauermann F, Eccles JS, Pekrun R. Why do children worry about their academic achievement? An expectancy-value perspective on elementary students' worries about their mathematics and reading performance. ZDM. 2017; 49(3): 339-354. [Link]

24. Bandura A. 50 the power of observational learning through social modeling. In: Sternberg RJ, Fiske ST, Foss DJ, editor. Scientists making a difference. Cambridge University Press; 2016, pp: 235-239. [Link] 